\title{
PHYTOCENOTIC STRUCTURE AND PHYSICO-CHEMICAL PROPERTIES OF A SMALL WATER BODY IN AGRICULTURAL LANDSCAPE
}

\author{
Joanna Sender, Agnieszka Kułak \\ Department of Landscape Ecology and Nature Protection, University of Life Sciences in Lublin \\ Dobrzańskiego 37, 20-262, Lublin \\ e-mail:joanna.sender@up.lublin.pl
}

Received: 30.03 .2013

\begin{abstract}
Small water bodies, until recently considered as wasteland, are an essential element of the so-called small water retention. Their main use can vary significantly, but they always play a positive role by increasing water resources and enhancing the natural values of the landscape. Moreover, by increasing biodiversity thanks to plants forming habitats for many species of flora and fauna, small water bodies act as a biofilter, improving water quality. But these small reservoirs belong to the groups of waters that are most exposed to damage, especially within the catchment area. Because of the invaluable role of small farmland water bodies, a study was undertaken to investigate their phytocenotic structure. In addition, an attempt was made to assess the level of threats and to indicate their role in the development of habitat conditions. The investigated reservoir was created in 2007. Before that time, it functioned as a part of the Zemborzycki reservoir, as they were close to each other. Almost the entire surrounding of this small reservoir consisted of farmland. In 2011 a revitalization project was carried out in the reservoir. Plants typical for wetland habitats were mainly introduced, while synanthropic vegetation was removed. Based on chemical and physical analyses, it can be concluded that the investigated reservoir serves as a natural biofilter thanks to the qualitative and quantitative changes in the structure of macrophytes. After the revitalization project, the investigated pond gained new aesthetic and ecological qualities.
\end{abstract}

Key words: small water body, water quality, macrophytes, anthropogenic impact

\section{INTRODUCTION}

Water in the natural environment, including agriculture, fulfills several important functions. On the one hand, it shapes the biodiversity and is an essential factor in preserving natural values, while on the other hand it determines potential crops and the level of economic de- velopment. The fulfillment of the conditions for sustainable development of agriculture requires, among others, complex water management within a small catchment. In these efforts, water has a leading role as a factor influencing the biological diversity and ecological balance. The role of agriculture in water management and in the natural environment increases with its intensification. The main sources of pollution from agriculture are mineral and organic fertilizers as well as leaks from septic tanks. Thus, large amounts of nitrogen and phosphorus enter the groundwater [1].

The concept of landscape management and use is important in order to treat agriculture and environmental protection on the same plane. This is necessary, because the rate of changes in the agricultural landscape, especially in suburban areas, is very fast.

In small catchments, there are three basic forms of water resources: surface water in reservoirs, groundwater, and aeration zone water. Small water bodies, until recently considered as wasteland, are an essential element of the so-called small water retention. Their main use can vary significantly, but they always play a positive role by increasing water resources and enhancing the natural values of the landscape [2]. Moreover, by increasing biodiversity thanks to plants forming habitats for many species of flora and fauna, small water bodies act as a biofilter, improving water quality $[3,4]$. Natural reservoirs retain up to $75-80 \%$ of sediments [5]. However, these small water bodies are also the most endangered [6].

Because of the invaluable role of small farmland water bodies, a study was undertaken to investigate their phytocenotic structure. In addition, an attempt was made to assess the level of threats and to indicate their role in the development of habitat conditions. 


\section{STUDY AREA}

Constructed on the Bystrzyca River, the Zemborzycki reservoir belongs to small, shallow, flow-through, urban and lowland water reservoirs with short water exchange time [7]. Because of these adverse characteristics [8], it is exposed to the supply of large quantities of material, in relation to its volume, which causes rapid eutrophication and deterioration of water quality. In addition to the accumulation of mineral sediments, there is an accelerated accumulation of organogenic sediments, the depth and the usable volume of the reservoir are decreasing, and its recreational qualities are diminishing $[9,10]$.

In 2007, after building a bike path along a large stretch of the western shore, one of the bays was cut off from the Zemborzycki reservoir, forming a separate reservoir in the immediate vicinity connected by a concrete culvert.

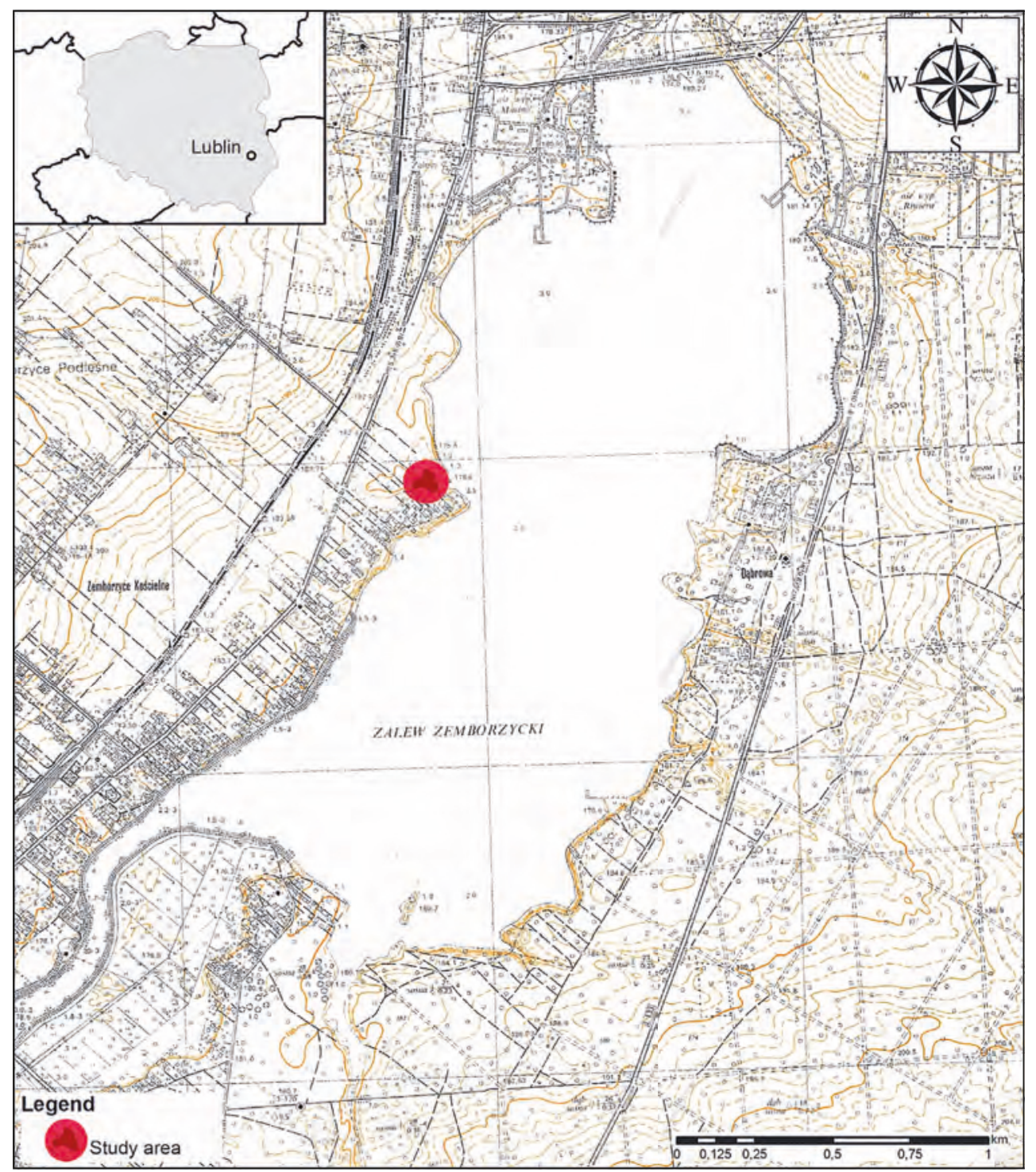

Fig. 1. Location of the study area.

The largest part of the reservoir catchment area comprises small intensively used fields. On the south side, there is a single-family residential neighborhood, as well as from the eastern side of the Zemborzycki reservoir. This is a small recess area, only 0.13 ha, constantly filled with water. Until 2010, this water reservoir was run down and functioned as a receptor of pollution; it was also used as an illegal rubbish dump. In 2011 some work was carried out which involved the removal of pollution and shrubs growing directly in the reservoir (Fig. 1). This work included cleaning as well as plantings in the water reservoir and on the shore. In its current form, it serves as a natural and educational path (Fig. 2) [11,12]. 

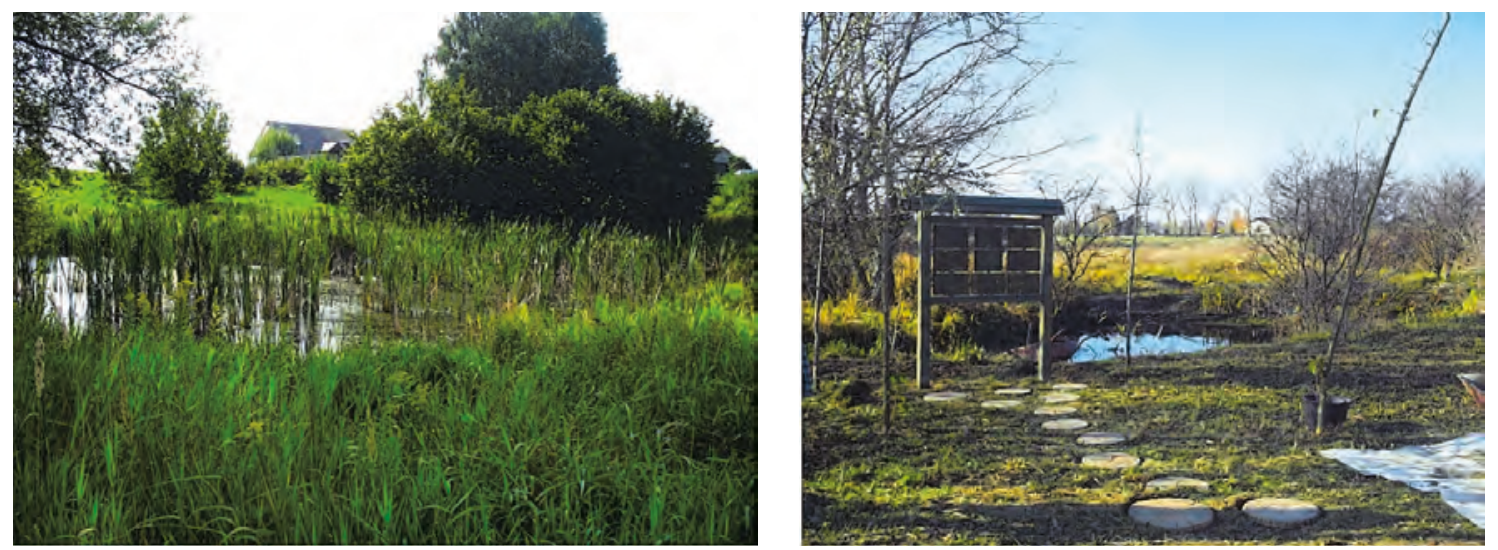

Fig 2. Northern (2011) and western (2012) part of the investigated area.

\section{MATERIALS AND METHODS}

Field investigations were conducted in 2011 and 2012 during three seasons - spring, summer and autumn. The study involved an analysis of physicochemical parameters of groundwater areas adjacent to the water reservoir, the reservoir itself, and of the Zemborzycki reservoir connected to it. In total, samples were collected from four study sites (Fig. 3).

Temperature, water $\mathrm{pH}$, electrolytic conductivity, oxygen content, total $\mathrm{P}$ and total $\mathrm{N}$ were analyzed.
The following instruments were used for the determination of physical and chemical properties of water: an OXI 330 oximeter manufactured by WTW (oxygen content, temperature), an electronic conductivity meter manufactured by Hanna (electrolytic conductivity), and a Slandi-produced microchip SP300 pH-meter (water $\mathrm{pH})$. The content of biogenic nitrogen and phosphorus compounds was determined using a microchip LF 205 photometer (Slandi). Carlson's [13] Trophic State Index (TSI) was calculated based on Secchi disk visibility (SD), nitrogen (TN) and phosphorus (TP) content.

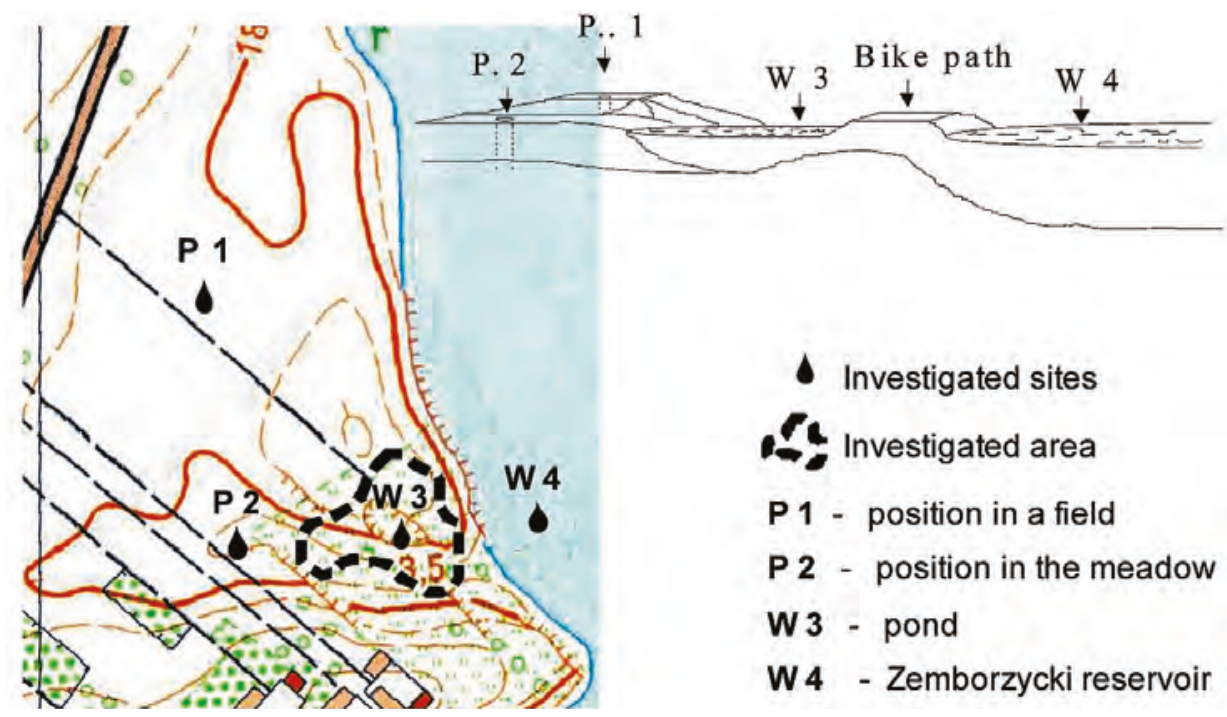

Fig 3. Distribution of study sites.

Simultaneously, a floristic survey was conducted in the small reservoir and in the Zemborzycki reservoir. The vegetation was studied in horizontal transects extending from the shoreline to the maximum depth of their occurrence $[14,15]$. The number of transects at each investigated site varied from 4 in the Zemborzycki reservoir to 8 in the small water body. Plant communities were examined and identified on the basis of vegetation relevés using the method of Braun-Blanquet [16]. The syntaxonomic system was adopted after M a t u s zki ew i c z [17]. The phytolittoral area and the length of the shoreline inhabited by macrophytes were determined on the basis of the actual vegetation map for the lakes using Macrostation ver. 8 . The analysis of land use was made using Corel software. 


\section{RESULTS}

Analysis of changes

in land use surrounding the reservoir

Based on the analysis of land use changes which occurred in 2007 and 2012 in the immediate vicinity of the reservoir, a clear reduction in uncultivated land was shown. The share of tree and shrub areas increased. The reason was the planting carried out in 2010 (Fig. 4).
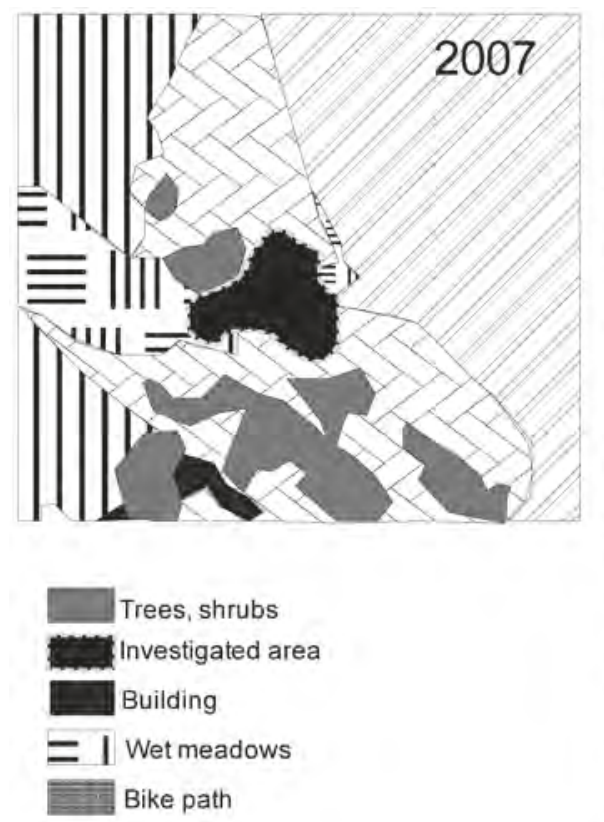

Fig. 4. Changes in land use surrounding the study area.

After cutting off the bay, the rush belt also increased significantly in the Zemborzycki reservoir (contact area) (Table 1).

Table 1

Percentage share (\%) of land use around the investigated area.

\begin{tabular}{lcc}
\hline \multicolumn{1}{c}{ Type of land use } & $\mathbf{2 0 0 7}$ & $\mathbf{2 0 1 2}$ \\
\hline Trees, shrubs & 13 & 15 \\
Buildings & 4 & 9 \\
Wet meadows & 11 & 13 \\
Bike path & 0 & 2 \\
Farmland & 35 & 21 \\
Wasteland & 36 & 17 \\
Rushes & 1 & 11 \\
Plantings of maple and ash & 0 & 12 \\
\hline
\end{tabular}

\section{Analysis of physico-chemical parameters}

The analyzed parameters showed significant differences between the study sites. Groundwater had the lowest temperature values. The water reservoir studied was characterized by the highest values of temperature, which resulted from morphological determinants (a shallow depth and the mass of water); it heated

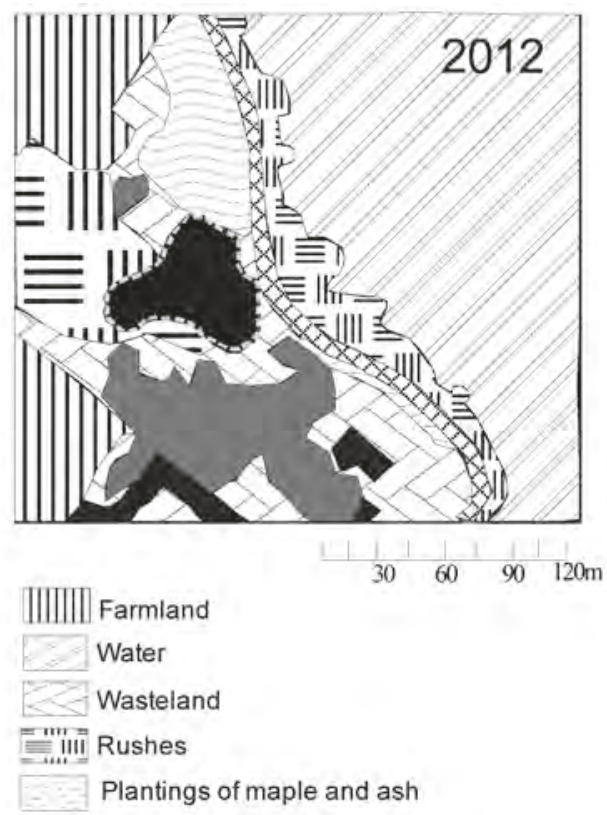

up very quickly under the influence of solar radiation (Table 2).

The most alkaline water was found in the Zemborzycki reservoir. The highest conductivity values were present in groundwater in the wet meadow (Table 2), inhabited by communities from Molinietalia, representing anthropogenic associations.

The penetration of oxygen from air to water occurs only at the surface of contact of these two spheres. Thus, stagnant waters absorb less oxygen than wavy waters. The scarcity of oxygen in the water resides in the fact that the ability of gas to dissolve decreases with increasing temperature. In the analyzed reservoir, the amount of oxygen was often lower than in the Zemborzycki reservoir. During the analyzed period, there was no supersaturation of water with this gas and thus the lack of algal blooms, in contrast to the waters of Zemborzycki reservoir.

Electrolytic conductivity is a measure of the ability to conduct electric current. There is a close relationship between conducting electric current and the content of electrolyte ions in the water. Pure water is a poor conductor of electricity; pollution causes better current conduction. The highest values of conductivity were observed in the groundwater of the adjacent area, and the lowest ones in the pond waters (Table 2). 
Table 2

Physical parameters of the investigated area.

\begin{tabular}{|c|c|c|c|c|c|c|c|c|c|c|c|c|c|c|c|c|c|}
\hline \multicolumn{2}{|l|}{ Factor } & \multicolumn{4}{|c|}{ Temp. ${ }^{\circ} \mathrm{C}$} & \multicolumn{4}{|c|}{$\mathrm{pH}$} & \multicolumn{4}{|c|}{ Hardness } & \multicolumn{4}{|c|}{$\begin{array}{l}\text { Electrolytic conductivity. } \\
\mu \mathrm{S} / \mathrm{cm}\end{array}$} \\
\hline Time/ & & P1 & $\mathbf{P} 2$ & W3 & W4 & P1 & $\mathbf{P 2}$ & W3 & W4 & P1 & $\mathbf{P 2}$ & W3 & W4 & P1 & $\mathbf{P 2}$ & W3 & W4 \\
\hline \multirow{2}{*}{ spring } & 2011 & 14 & 15.5 & 20.2 & 16.9 & 6.2 & 7.6 & 6.82 & 8.95 & & & & & 403 & 497 & 356 & 396 \\
\hline & 2012 & 13.8 & 12.7 & 19.7 & 16.9 & 7.6 & 7.8 & 7.5 & 8.3 & 15.44 & 7.9 & 6.12 & 12.06 & & 699 & 310.5 & 267 \\
\hline \multirow{2}{*}{ summer } & 2011 & 16.2 & 17.8 & 19.5 & 20.9 & 6.35 & 7.06 & 7.5 & 9.03 & & & & & 220 & 219 & 301 & 321 \\
\hline & 2012 & 15.8 & 16.9 & 19.5 & 23.7 & 7.6 & 7.8 & 8.6 & 8.31 & 8.53 & 24.5 & 7.78 & 12.56 & & 706 & 347.2 & 333.9 \\
\hline \multirow{2}{*}{ autumn } & 2011 & 12 & 12.8 & 13.1 & 15.4 & 6.4 & 7.1 & 7.56 & 8.56 & & & & & 215 & 628 & 306 & 382 \\
\hline & 2012 & 7.8 & 8.7 & 8 & 7 & 7.7 & 7.8 & 8.3 & 8.4 & 3.15 & 7.79 & 14.41 & 16.24 & 274.5 & 667 & 537 & 469 \\
\hline
\end{tabular}

Nitrogen and phosphorous compounds are factors affecting the process of eutrophication. Studies so far have shown that the main factor limiting the development of biomass in the freshwater environment is phosphorus. The main source of phosphorous is agriculture $-50 \%$, and urban waste $-41 \%$. Among agricultural sources, livestock is considered to be the most important $-34 \%$, while fertilizers are relatively less important $-16 \%$ [18]. The threat of aquatic eutrophication from agriculture is growing with increasing intensity of agricultural production. The surroundings of the pond comprise, in a major part, land used for agricultural purposes. Hence, the role of the small reservoir is huge. This is confirmed by the values of the analyzed compounds of nitrogen and phosphorus. In this case, the pond acts as the initial reservoir, reducing the amount of pollutants, and contributes to improving the quality of water in the Zemborzycki reservoir (Table 3).

The highest values of organic nitrogen and nitrates were found in the water flowing from the farm field. In 2011 the field was planted with sugar beet, which is a plant with high nutritional requirements. Foliar feeding was used in the spring, which immediately resulted in high contents of nitrogen in groundwater. In 2012 cereal and leguminous mixed crops were grown in the field and nitrogen concentrations were much lower.

In general, the lowest values of nutrients were found in the waters of the Zemborzycki reservoir where the pond waters affected this reservoir. Groundwater showed by far the highest values (Table 3).

An important indicator of conditions particularly favorable to the development of submerged macrophytes is Secchi disk visibility. The greater range of sunlight penetration, the higher is the colonization by this group of macrophytes. Higher values of this index were found in the water sampled from the Zemborzycki reservoir, and it also resulted in a greater diversity of macrophytes (Fig. 5).

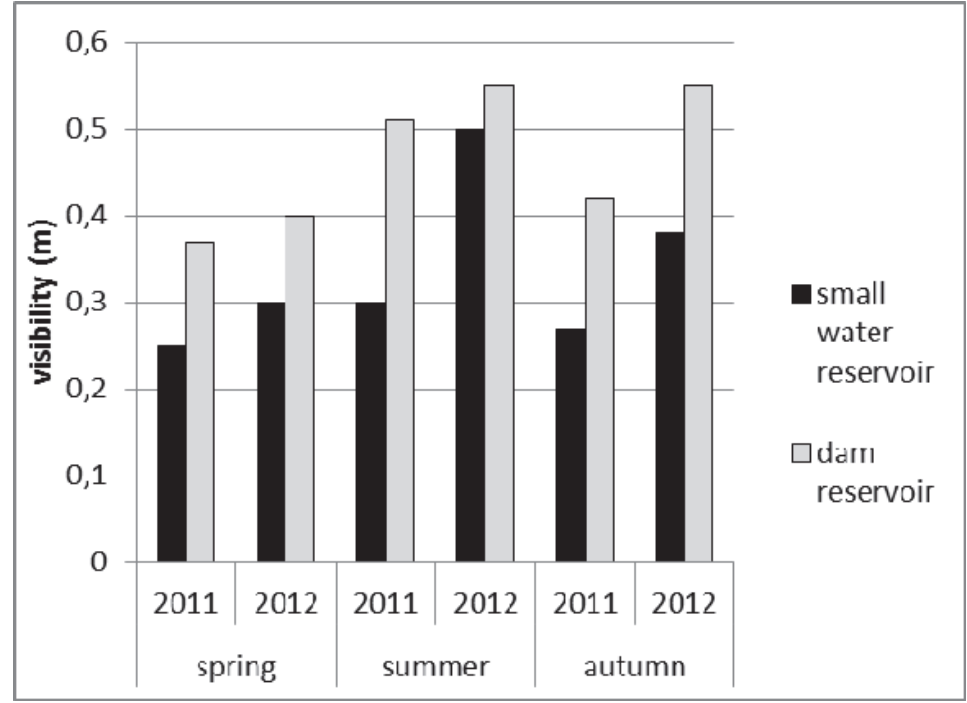

Fig. 5. Light conditions in the waters of the investigated area (Secchi disc visibility). 
Table 3

Chemical properties in the investigated area.

\begin{tabular}{|c|c|c|c|c|c|c|c|c|c|c|c|c|c|c|c|c|c|c|c|c|c|c|c|c|c|}
\hline \multirow{2}{*}{\multicolumn{2}{|c|}{$\frac{\text { Factor }}{\text { Time/position }}$}} & \multicolumn{4}{|c|}{$\mathrm{mg} \mathrm{O}_{2} / \mathrm{l}$} & \multicolumn{4}{|c|}{$\begin{array}{l}\text { organic nitrogen } \\
\mathrm{mg} \mathrm{N} / \mathrm{l}\end{array}$} & \multicolumn{4}{|c|}{$\mathrm{mg} \mathrm{NH}_{4} / \mathrm{l}$} & \multicolumn{4}{|c|}{$\mathrm{mg} \mathrm{NO} / \mathrm{l}$} & \multicolumn{4}{|c|}{ phosphorus mgP/l } & \multicolumn{4}{|c|}{$\mathrm{mg} \mathrm{PO}_{4} / \mathrm{l}$} \\
\hline & & P1 & P2 & W3 & W4 & $\mathrm{P} 1$ & P2 & W3 & W4 & $\mathrm{P} 1$ & P2 & W3 & W4 & P1 & P2 & W3 & W4 & $\mathrm{P} 1$ & P2 & W3 & W4 & P1 & P2 & W3 & W4 \\
\hline \multirow{2}{*}{ spring } & 2011 & & - & 6.09 & 12.9 & 23.1 & 2.3 & 4.2 & 1.4 & 0.12 & 0.24 & 0.45 & $<0.1$ & 65.44 & 0.5 & 0.845 & 0.27 & & & & 0.26 & 0.452 & 0.318 & 0.886 & $<0.1$ \\
\hline & 2012 & & 16.52 & 10.2 & 10.0 & 1.79 & 0.79 & $<0.50$ & $<0.50$ & 1.077 & 2.268 & 1.016 & 1.311 & 2.41 & 1.13 & $<0.1$ & $<0.1$ & 2.89 & 2.37 & 0.109 & 0.181 & 0.551 & 0.504 & 0.214 & 0.01 \\
\hline \multirow{2}{*}{ summer } & 2011 & & - & 8.4 & 5.32 & 2.5 & 2 & 1.5 & 0.47 & 0.18 & 0.23 & 0.28 & $<0.1$ & 3.86 & 1.17 & 1.36 & $<0.1$ & & & & 0.28 & 0.545 & 0.432 & 0.052 & $<0.1$ \\
\hline & 2012 & - & & 10.6 & 11.5 & & 0.5 & $<0.5$ & $<0.5$ & & 2.71 & 0.513 & 1.3 & & 0.1 & & & 0.9 & 0.6 & 0.222 & 0.637 & & 0.01 & 0.036 & 0.01 \\
\hline \multirow{2}{*}{ autumn } & 2011 & & - & 7.06 & 8.9 & 0.1 & 2.6 & 1.3 & 1.11 & 0.2 & 1.86 & 0.31 & $<0.1$ & 0.65 & 0.09 & 0.14 & $<0.1$ & & & & 0.18 & 0.175 & 0.123 & 0.079 & $<0.1$ \\
\hline & 2012 & - & - & 16.3 & 5.94 & 3.99 & 1.7 & 6.02 & 2.68 & 2.8 & 1.039 & 0.729 & 0.679 & 1.36 & 1.15 & 0.78 & 2.06 & 0.87 & 0.35 & 0.26 & 0.224 & 0.204 & 0.366 & 0.098 & 0.03 \\
\hline
\end{tabular}

Carlson's index values for the individual study sites indicate their eutrophic or even hypertrophic character. However, there is a clear downward trend in the direction of open water (Fig. 6). These differences were statistically significant only in the case of two sites: in the Zemborzycki reservoir (W4) and in the field (P1) (Test $\mathrm{F}=2.4, \mathrm{p}=0.05$ ).

TSI

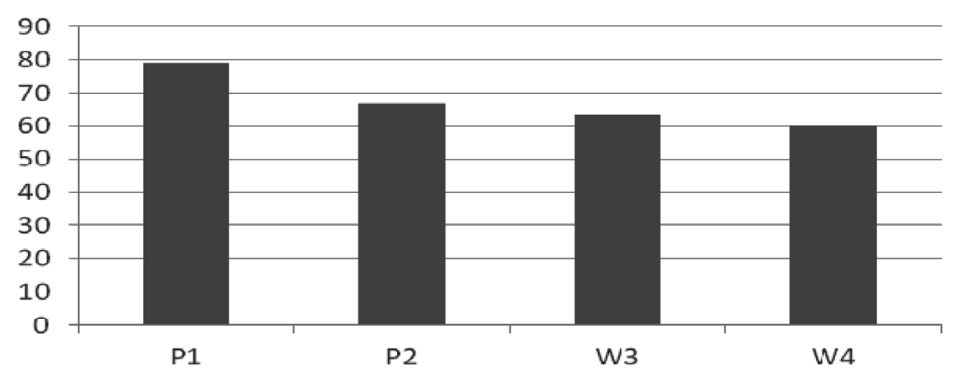

Fig. 6. Carlson's index value for the study sites.

\section{Floristic analysis of the study area}

The analyzed area occupied about $126 \mathrm{~m}^{2}$ (1.3 are) with a maximum depth of $1 \mathrm{~m}$ (on average
$0.6 \mathrm{~m})$. Due to its morphometric parameters and distribution of vegetation, conditions typical for fish ponds dominated there $[19,20]$.

Table 3

The percentage share $(\%)$ of different plant communities in the study area

\begin{tabular}{lccc}
\hline \multicolumn{1}{c}{ Plant community } & $\mathbf{2 0 0 7}$ & $\mathbf{2 0 1 1}$ & $\mathbf{2 0 1 2}$ \\
\hline \multicolumn{1}{c}{ Ceratophylletum demersi } & Area (\%) & 50 \\
Lemno minoris -Salvinietum natantis & 91 & 19 & 5 \\
Urtico-Calystegium sepium & 6 & 10 & - \\
Typhetum latifoliae & 36 & 25 & 19 \\
Scirpetum silvatici & 11 & 5 & 1 \\
Phalaridetum arundinaceae & - & - & 1 \\
Glycerietum maximae & 20 & 5 & 5 \\
Calystegio-Eupatorietum & 2 & 5 & - \\
Utrico-Aegopodirtum podagrariae & - & 5 & - \\
Sambucetum nigrae & - & 2 & - \\
Nupharo-Nymphaeetum albae & - & - & 10 \\
Hydrocharitetum morsus-ranae & - & - & 4 \\
Iridetum pseudoacori & & & 5 \\
Surface of phytolittoral (ar) & 0.12 & 0.13 & 0.10 \\
\hline
\end{tabular}


In 2007 almost the whole bay was covered with Typha rushes, with a large share of Glyceria maxima and Scirpus silvaticus. Almost the entire pelagic zone was overgrown with Ceratophyllum demersum. In 2011, after cutting off the bay but before rehabilitation carried out in the autumn, the bottom of the reservoir was covered in about $20 \%$ by Ceratophyllum demersum, Lemna minor and Spirodela polyrhiza, while Polygonum amphibium occurred occasionally. In addition, the whole reservoir was covered with plants, especially Typha latifolia (Table 3).

The gentle shore from the meadow side was covered with Carex hirta, Equisetum fluviatile, Phalaris arundinacea, Utrica dioica, and Typha latifolia. There were also Chamomilla recutita, Papaver rhoeas, Vicia sepium, and Poa palustris.

The entire surface of the reservoir was covered with macrophytes, with a large proportion of pleustonic macrophytes, which considerably reduced the occurrence of submerged macrophytes. The steep banks were covered with Phalaris arundinacea, Eupatorium cannabinum, Utrica dioica and single individuals of Typha latifolia. The share of ruderal species was by far the largest in this period.

Revitalization work carried out consisted in introducing to this area typical aquatic habitat species, among others: Iris pseudoacorus, Hydrocharis morsusranae, and Nuphar lutea. Following that revitalization, the analyzed reservoir was characterized by a great diversity of plant species. The number of communities inhabiting them did not increase, but their qualitative composition was rebuilt. Ruderal species disappeared and in their place aquatic species were introduced. It is a sort of ecotone - a transition zone between two diverse aquatic and terrestrial ecosystems.

Based on the analyses, the relationship was investigated between the occurrence of particular groups of macrophytes forming the littoral zone and the concentration of some nutrients (nitrogen and phosphorus). It was shown that higher concentrations of the analyzed parameters were in the reservoir when ruderal species and rushes dominated. However, the concentrations were lower when submerged macrophytes dominated. This relationship is confirmed by the high value of the correlation coefficient, which was for nitrogen $(r=0.79, p<0.05)$, while for phosphates $(r=$ $0.67, \mathrm{p}<0.05)$.

\section{DISCUSSION}

Revitalization projects are focused on the recovery of degraded and damaged areas. The aim is to give a new use to such areas of and to achieve a state in which their function changes for a new one. As a result of anthropogenic activities, landscape is continually changing, transforming its elements and characteristics. These changes are caused by almost every kind of human activity, but the most intense changes occur in urbanized and industrialized areas. The expansion of human activity leads, inter alia, to the conversion of geomechanical terrain, habitat and soil cover degradation, changes in the water cycle resulting in the intensification of surface runoff and subsurface infiltration reduction. In addition, it contributes to the discharge of wastewater and waste into the environment and changes in the mezzo-climate.

Bodies of water, including those created by man, are one of the environmental elements that are important in landscape revitalization. They are currently perceived by people as features that can be used for recreation as well as an enclave with unique natural environmental values [21]. Therefore, areas adjacent to any kind of reservoirs should be ordered and harmoniously developed. These activities, together with ecology-oriented projects, should cover the whole catchment area and include protective measures in the reservoir itself. Such consolidated actions will allow the gradual improvement of the ecological status [22]. Only such a method will reduce the eutrophication of reservoirs, which results in the reduction of natural and landscape values [23].

Most of plant communities occurring on the shore of the reservoir are typical of wet soil and rich in nutritional compounds. The Scirpetum sylvatici community forms interesting inflorescences in aesthetic terms, which can be useful for shaping the edges of water bodies. Eupatorium cannabinum and Lysimachia vulgaris may also have similar application. In the vicinity of the buildings, there was a dense belt of Corylus avellana, while from the Zemborzycki reservoir communities of Aegopodium podagraria and Utrica dioica developed; they are often a replacement system for riparian forest communities [17].

The flowering of herbaceous plants, dominated by Aegopodium podagraria, is accompanied by an interesting visual effect. Communities with a majority of Utrica dioica are a result of over-fertilization of meadows with liquid manure and farmyard manure and they grow at places of particularly high nitrogen and phosphorus concentration in the soil [24].

Many species occurring in the vicinity of the pond are the result of successional processes whose pace, due to the activities carried out within the reservoir catchment and neglect, has significantly accelerated, pushing the plants out their natural habitats. Unwanted species in this environment include the following: walnut, hazel, mirabelle plum, and elderberry. With an increase in the water level, other species disappeared and only vegetation appropriate for this type of habitats survived. 
From the point of view of usability of the reservoir, the most important was to maintain the highest species diversity of submerged aquatic plants and rushes. Ceratophyllum demersi, a very common species found in standing and slow moving waters across the whole country, occurred most frequently. It is characterized by a large expansion. It tolerates low transparency and among submerged species is one of the most deeply found water species. It would be valuable to maintain it, because in the Zemborzycki reservoir it disappeared completely a few years ago [25]. This tendency to disappear was also clear in the analyzed reservoir in 2011.

With an increase in the water level, other species disappeared and only vegetation appropriate for this type of habitats survived. The examined reservoir is subject to very intense changes. Proper development of the reservoir would include increasing its self-cleaning capabilities, and thus it would have a beneficial effect on the waters of the Zemborzycki reservoir. The unfavorable location of the reservoir, among fields and buildings, is a major risk affecting the rate of change in its floristic composition. From the point of view of its proper role, it should be maintained in accordance with the type of habitat.

\section{Acknowledgements}

The project of revitalization was financed by Municipality of Lublin City, Department of Enviromental Protection.

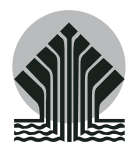

Co-financed by National Fund for Environmental Protection and Water Management

\section{Authors' contributions}

The following declarations about authors' contributions to the research have been made: concept of the study: JS; field works: JS, AK; chemical analyses: JS; writing of the manuscript: JS; revitalization project: AK; photographs: AK.

\section{REFERENCES}

1. Izydorczyk K, Frątczak F, Drobniewska A, Badowska M, Zalewski M. Zastosowanie stref ekotonowych w ograniczaniu zanieczyszczeń obszarowych. Przegląd Komunal. 2010; 10: 79-81.

2. Hilbricht-Ilkowska A. Strategia ochrony różnorodności biologicznej ekosystemów słodkowodnych. In: Ryszkowski L, Bałazy S, (eds) Poznań: Bonami; 1999: 37-58.
3. Pień kowski P. Analiza rozmieszczenia oczek wodnych oraz zmian w ich występowaniu na obszarze Polski północno-zachodniej. Rozpr Monogr. 2003; 222: 122.

4. Mioduszewski W. Małe zbiorniki wodne. Falenty: IMUZ; 2006.

5. Szwerański $\mathrm{S}$. The influence of the small reservoirs on the amount of suspended sediment in a stream and the sediment yield value. EJPAU, Environ. Develop, 2002; 5.2.

6. Kalbarczyk R. Oczka wodne w agroekosystemach: geneza i charakterystyka oczek wodnych. Aura. 2003; 12: 24-25.

7. Rodzik J, Dobrowolski R, Melke J. Estimation of kind, amount and mechanism of sedimentation in the Zemborzyce reservoir near Lublin. Teka Kom Ochr Środ Przyr. 2009; 6: 261-276.

8. Kasza H. Antropopresja a rozwój trofii wody w zbiornikach zaporowych. In: Mater. Konf. Nauk.: „Biologiczne aspekty funkcjonowania zbiorników zaporowych”. Akademia Rolnicza w Lublinie. 1999. p. 9-12.

9. Michalczyk Z, editor. The strategy of utilization and the protection of waters in river - the basin Bystrzyca. Hydrographic investigations in cognition of the environment. Lublin: Wyd UMCS; 1997. (vol 5).

10. Radwan S, editor. Zemborzycki Reservoir - ecological structure, anthropogenic dangers and protection. Lublin: Wyd AR; 2006.

11. Sender J, Kułak A. Significance and development of small water body in the immediate vicinity of Zemborzycki water reservoir in Lublin. Teka Kom Ochr Środ Przyr. 2010; 7: 365-373.

12. S e nde r J, editor. Przyrodnicze i dydaktyczne zagospodarowanie oczka wodnego w sąsiedztwie 2 lagun fitolitoralowych Zalewu Zemborzyckiego. In: Raport z realizacji zadania badawczego. Lublin: Wydz Ochr Środ UM; 2011. p. 55.

13. Carls on RE. A trophic state index for lakes. Limnol Ocean. 1977; 22(2): 361-369. http://dx.doi.org/10.4319/lo. 1977.22.2.0361

14. Sender J. Struktura jakościowa i ilościowa zbiorowisk makrofitów w wybranych jeziorach Pojezierza Łęczyńsko-Włodawskiego [PhD thesis]. Poznań: UAM; 2004.

15. S ender J. The dynamics of macrophytes in a lake in an agricultural landscape. Limnol. Rev. 2012; 12(2): 93-100. http://dx.doi.org/10.2478/v10194-011-0049-6

16. D z w on ko Z. Przewodnik do badań fitosocjologicznych. Cracow: Instytut Botaniki UJ; 2007.

17. Matuszkiewicz W. Przewodnik do oznaczania zbiorowisk roślinnych Polski. Warsaw: Polish Scientific Publishers PWN; 2008.

18. Leaf SC, Chatterjee R. Developing a strategy on eutrophication. Water Sci Technol. 1999; 39(12): 307-314. http://dx.doi.org/10.1016/S0273-1223(99)00348-0

19. S ender J. Hydrobotaniczna charakterystyka stawów Poleskiego Parku Narodowego. Ekol Tech. 2011; 19(3): 145-151.

20. S e nder J. Makroflora wodna i szuwarowa [Aquatic and rush macroflora]. In: Kornijów R, Buczyński P, (eds) Jezioro Skomielno (Pojezierze Łęczyńsko-Włodawskie, Polska 
Wschodnia). Monografia przyrodnicza [Lake Skomielno (Łęczna-Włodawa Lakeland, Eastern Poland). Environment monograph]. Wydawnictwo Mantis, Olsztyn; 2012: 83-97.

21. Celiński F, Czylok A, Kubiak A. The natural guide after Dąbrowa Górnicza. Krzeszowice: Kubajak; 2001.

22. Rzętała M. Shore processes and the bottom sediments in some water reservoirs in under diverse anthropopression (with the use of an example of Silesian Upland and surrounded areas). Pr Nauk Uniw Śląskiego W Katowicach. 2003; (2169): 147.

23. Kaja k Z. Eutrophication of lowland water reservoirs. In: Zalewski M, editor. Biological processes in protection and the reclamation of lowland water reservoirs. Łódź: Bibl Monit Środ PIOŚ WIOŚ ZES IŁ; 1995. p. 33-41.

24. Wysocki C, Sikorski P. Fitosocjologia stosowana. Warsaw: SGGW; 2002.

25. S ender J. Sources of threats and directions of macrophytes structure changes in the Zemborzycki Reservoir. Teka Kom Ochr Środ Przyr. 2007; 4: 221-228.

\section{Struktura fitocenotyczna oraz właściwości fizyczno-chemiczne wód małego zbiornika krajobrazu rolniczego}

\section{Streszczenie}

Małe zbiorniki wodne, do niedawna uważane za nieużytki, są podstawowym elementem tzw. małej retencji. Zasadnicze przeznaczenie może być bardzo różne, ale zawsze pełnią pozytywną rolę zwiększając zasoby wodne i wzbogacając walory przyrodnicze krajobrazu. Dodatkowo poprzez zwiększanie różnorodności biologicznej, dzięki roślinom je porastającym i tworzącym siedliska dla wielu gatunków flory i fauny, małe zbiorniki wodne pełnią rolę biofiltra, poprawiając jakość wody. Jednakże te małe zbiorniki wodne należą także do najbardziej zagrożonych. Ze względu na nieocenioną rolę małych zbiorników wodnych krajobrazu rolniczego, zostały podjęte badania obejmujące analizę ich struktury fitocenotycznej. Ponadto, podjęto próbę oceny stopnia zagrożenia i wskazanie jego roli w rozwoju warunków siedliskowych. Badany zbiornik powstał w 2007 roku. Wcześniej funkcjonował jako jedna z zatok Zalewu Zemborzyckiego. Niemalże całe bezpośrednie otoczenie małego zbiornika wodnego stanowiły pola uprawne. W roku 2011 przeprowadzono na tym terenie prace rewitalizacyjne. Wprowadzono głównie rośliny siedlisk wodno-błotnych, usunięto zaś gatunki roślinności synantropijnej. W oparciu o wyniki fizyczno-chemicznych analiz wody zbiornika oraz wód podziemnych i powierzchniowych w bezpośrednim jego otoczeniu można wnioskować, iż funkcjonuje on jako naturalny biofiltr. Zmiana w obsadzie roślin z pewnością wzmocniła proces oczyszczania wód, przepływających poprzez zbiornik do Zalewu. Po przeprowadzonych pracach rewitalizacyjnych mały zbiornik wodny krajobrazu rolniczego zyskał nowe wartości ekologiczne i estetyczne.

\footnotetext{
Handling Editor: Elżbieta Pogroszewska
}

This is an Open Access digital version of the article distributed under the terms of the Creative Commons Attribution 3.0 License (creativecommons.org/licenses/by/3.0/), which permits redistribution, commercial and non-commercial, provided that the article is properly cited. 